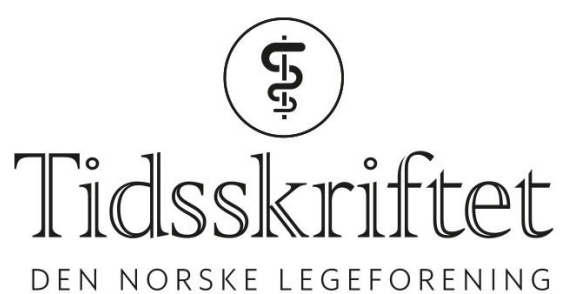

DEN NORSKE LEGEFORENING

\title{
Fekaltransplantasjon og mikrobiom
}

KOMMENTAR

\section{STIG S. FRøLAND}

E-post: s.s.froland@medisin.uio.no

Stig S. Frøland er professor emeritus. Ingen oppgitte interessekonflikter.

Frederik Emil Juul og Jørgen Valeur ønsker å innføre betegnelsen tarmflorabehandling for den behandlingsformen som i engelskspråklig litteratur kalles "fecal microbiota transplantation» eller, i økende grad bare "fecal transplantation» (1). Jeg synes ikke deres argumenter for dette er overbevisende.

Slik behandlingen i dag utføres, må den norske betegnelsen «fekal transplantasjon» være dekkende. Når forfatterne under henvisning til Store medisinske leksikon innvender at transplantasjon skal være «overføring av celler, vev eller organer innen et individ eller mellom to individer», og de videre hevder at i fekal transplantasjon «inngår ikke engang våre egne celler», glemmer de at xenotransplantasjon tross alt er basert på transplantasjon mellom ulike dyrearter.

Når de hevder at «strengt tatt er tarmkanalen et rør utenfor mennesket selv» og ikke er «et organ i klassisk forstand», er det en svært formalistisk innvending, som faktisk ignorerer våre økte kunnskaper om tarmens mikrobiom som en integrert del av menneskeorganismen, med en vesentlig innflytelse på individets utvikling og helsetilstand. Et viktigere spørsmål for terminologisk avklaring er bruken av betegnelsen mikrobiom versus mikrobiota. Her er det fortsatt ingen konsensus i internasjonal litteratur hvor hele tre oppfatninger gjør seg gjeldende. Mange benytter betegnelsen mikrobiom om den samlede genmasse i mikrobefloraen i for eksempel tarmen, mens mikrobiota er betegnelsen på den totale mikrobeflora. Andre, for eksempel Store norske leksikon, skiller ikke mellom de to betegnelsene (2). Enkelte hevder også at mikrobiomet ikke bare omfatter den samlede mikrobeflora, men også floraens omgivelser («theatre of activity») (3). Her bør vi samle oss om én betegnelse, trolig den førstnevnte.

\section{LITTERATUR:}

1. Juul FE, Valeur J. Tarmflorabehandling. Tidsskr Nor Legeforen 2019; 139. doi: 10.4045/tidsskr.19.0058. [CrossRef]

2. Mikrobiom AH. https://snl.no/mikrobiom Lest 17.6.2018.

3. Young VB. The role of the microbiome in human health and disease: an introduction for clinicians. BMJ 2017; 356: j831. [PubMed][CrossRef] 
Publisert: 19. august 2019. Tidsskr Nor Legeforen. DOI: 10.4045/tidsskr.19.0445

(c) Tidsskrift for Den norske legeforening 2020. Lastet ned fra tidsskriftet.no 